\author{
Andrii Sulym $^{1}$, Oleksandr Safronov ${ }^{2}$, Inna Gladkykh ${ }^{3}$, Nadiia Lupitko $^{4}$ \\ ${ }^{1}$ State Enterprise "Ukrainian Scientific Railway Car Building Research Institute", 33, I. Prykhodka St., \\ Kremenchuk, 39621, Ukraine. ORCID: https://orcid.org/0000-0001-8144-8971 \\ ${ }^{2}$ State Enterprise "Ukrainian Scientific Railway Car Building Research Institute", 33, I. Prykhodka St., \\ Kremenchuk, 39621, Ukraine. ORCID: https://orcid.org/0000-0002-5865-7756 \\ ${ }^{3}$ State Enterprise "Ukrainian Scientific Railway Car Building Research Institute", 33, I. Prykhodka St., \\ Kremenchuk, 39621, Ukraine. ORCID: https://orcid.org/0000-0002-8674-2659 \\ ${ }^{4}$ State Enterprise "Ukrainian Scientific Railway Car Building Research Institute", 33, I. Prykhodka St., \\ Kremenchuk, 39621, Ukraine. ORCID: https://orcid.org/0000-0003-3387-2000
}

*Corresponding author:innagladkih59@gmail.com

\title{
STUDY OF PERFORMANCE INDICATORS OF TRANSPORT MACHINE-BUILDING AND RAILWAY INDUSTRY ENTERPRISES IN A PANDEMIC CONDITION COVID-19
}

The article analyzes the impact of the consequences of the quarantine measures introduction to counter the pandemic COVID-19 on the economy of Ukraine in general and the domestic transport machinebuilding sector in particular. It has been established that one of the most affected sectors of the economy is transport and mechanical engineering, in particular the railway transport sector. It is determined that at present a very relevant issue for the further development of domestic enterprises of transport machinebuilding and railway industry is the assessment of the impact of the COVID-19 pandemic on the activities and financial and economic performance of these enterprises. The financial and economic indicators of such domestic enterprises of transport machine-building and railway industry, such as JSC "Ukrzaliznytsia", PJSC "KVBZ", SE "UkrNDIV", LLC "LEMTRANS" and LLC "KERNEL-TRADE", TDV "Popasnyansky Car Repair Plant" are analyzed. It was determined that the most affected of the studied domestic enterprises under the conditions of quarantine measures were JSC "Ukrzaliznytsia", PJSC "KVBZ", TDV "Popasnyansky Car Repair Plant". The main reasons for the decrease in technical and economic indicators at domestic enterprises of transport machine-building and the railway industry are studied by the method of expert evaluation. According to the analysis of expert evaluation data, the most important reason for the deterioration of technical and economic indicators of enterprises is the lack of state support and incentives for the development of transport machine-building and the railway industry in the country (19.6\%). Experts estimate the impact of the consequences of the introduction of quarantine measures to counter the COVID19 pandemic at $8.1 \%$. Measures are proposed to improve the technical and economic performance of the most affected domestic enterprises of the transport machine-building and railway industries in the context of the COVID-19 pandemic.

Keywords: domestic enterprise, railway industry, COVID-19 pandemic, resource-saving technologies, technical and economic indicators, transport machine-building.

Introduction and problem statement. Throughout its historical existence, mankind has faced many crises, which later became the driving force for the development of society as a whole. At the end of 2019, humanity faced a fundamentally new catastrophe - the COVID-19 coronavirus pandemic, which spread rapidly around the world. As a result, in order to slow down the spread of the disease caused by COVID-19, governments have introduced quarantine measures at the legislative level. Quarantines, closing of borders, restriction on human mobility, creation of numerous problems practically for all states, all these are realities of today. The COVID-19 pandemic has changed not only the lives of many people, but also the situation in global and local markets. There has been a

Збірник наукових праць ДУІТ. Серія «Транспортні системи і технології», 2021. Вип. 38 
significant reduction in production capacity around the world due to the closure of borders between countries and the introduction of a regime of self-isolation. The spread of the epidemic disrupted the usual trade relations between producers and consumers, made serious changes in the activities of enterprises and companies. Many businesses around the world began to close, which resulted into that during the quarantine there was no one and nothing to transport due to unclear rules of the game.

Analysis of recent research. This issue was widely presented at the meeting of the United Nations General Assembly. Many heads of state expressed their opinion on the need for global renewal of all areas of human life. According to the World Health Organization and research, it is known that the effects of the COVID-19 pandemic will be remedied for decades.

The opinions of scientists around the world on this global issue have already been published and the impact of the effects of the COVID-19 pandemic depending on the sector of the economy has been partially revealed. These are primarily studies of D.V. Dolbnieva [1], M.F. Mizintseva [2], A. Flahault [3], H. Legido-Quigley, J.T. Mateos-Garcia, A. Campos [4], S. Kannan, Ali P. Shaik Syad, A. Sheeza, Hemalatha [5], S.I. Dolgova, Y.A. Savinova, E.V. Taranovskaia [6], L.H. Taylor, S.M. Latham, Woolhouse [7], Puriwat W., Tripopsakul S. [8], Giones F., Brem A., Pollack J.M., Michaelis T.L. M.E. 9], J. Zhan [10] and others.

However, the impact of quarantine measures to counter the COVID-19 pandemic on the activities of the domestic transport sector, in particular enterprises and companies in the transport machinebuilding and railway industries, has only been partially addressed. This is due to the fact that not enough time has passed to analyze and assess the impact on the domestic transport sector caused by the effects of the COVID-19 pandemic. Some of the domestic scientists have already begun to deal with this issue in their papers.

In the study [11] the state of the global economic situation in the field of maritime transport during the pandemic COVID-19 was examined, the relationship and impact of factors on the state of the world economy were analyzed; the ways to overcome the effects of the pandemic in the field of maritime transport were identified.

The study [12] deals with the problem of providing the protectionism of entrepreneurship in the framework of financial investment in a pandemic COVID-19. The conditions for classifying the sectors of the economy among the most affected by the pandemic in the context of state protectionism are proposed. According to the results of the rating, the energy, agricultural industry and transport need the largest financial allocations according to the COVID-19 impact index.

In papers $[13,14]$ the issue of the impact of the COVID-19 pandemic on the world economy, freight and passenger rail transportation is considered. In paper [13] the activities of all types of transport and railways of Ukraine, i.e., transit, import, export, domestic, are analyzed according to the indicators of traffic volumes and freight turnover. Factors influencing the state and change of these indicators for JSC "Ukrzaliznytsia" are singled out. Measures to reduce the negative impact of various factors on the state and development of the rail freight market are proposed. The study [14] found that one of the most affected industries is machine -building industry (there was a reduction in production by an average of 18.5\%). At the same time, the largest reduction was recorded in the production of vehicles, in particular in railcar- building.

According to the analysis of the latest research, one of the most affected sectors of the economy is transport and engineering, in particular domestic enterprises whose activities are related to the railway industry. At the same time, an important and relevant issue for the further development of the railway transport industry is the assessment of the impact of the COVID-19 pandemic on the activities and financial and economic performance of enterprises whose activities are related to the railway industry. It should be noted that this issue is poorly studied and remains open. Therefore, in order to develop ways and effective mechanisms for overcoming the crisis of domestic enterprises of transport machine-building and the railway industry, later in this article it is proposed to consider the scale and consequences of the COVID-19 pandemic on the work of these enterprises and their financial and economic indicators.

The aim is to investigate the impact of the COVID-19 pandemic on domestic enterprises whose activities are related to the railway industry by analyzing their financial and economic indicators and applying the

Збірник наукових праць ДУІТ. Серія «Транспортні системи і технологї̈, 2021. Вип. 38 
method of expert evaluation; to identify possible ways to overcome the effects of the pandemic at these enterprises.

Material and research results. The first cases of acute respiratory disease COVID-19, caused by the coronavirus SARS-CoV-2, were recorded in late 2019 in the Chinese city of Wuhan. In early 2020, governments began quarantine measures to slow the spread of the COVID-19 pandemic. In Ukraine, quarantine measures were introduced in accordance with the Resolution of the Cabinet of Ministers of Ukraine "On prevention of the spread of coronavirus COVID-19 in Ukraine" dated March 11, 2020 No. 211 (hereinafter referred as the Resolution). As of today, this Resolution is in force with numerous changes. In general, from the beginning of the implementation of quarantine measures until today (as of October 18, 2021) 27 amendments were made to the Laws of Ukraine, 2 decrees of the President of Ukraine, 217 Resolutions and 40 Orders of the Cabinet of Ministers of Ukraine aimed at overcoming the consequences of the COVID-19 pandemic-19 were issued. Thus, from the beginning of 2020, the economy of Ukraine and the enterprises of transport engineering and the railway industry in particular, began to feel the impact of antiepidemic measures. Therefore, in this paper it is proposed to consider the impact of quarantine measures on the work of these enterprises by comparing their financial and economic indicators based on the results of activities in 2019 and 2020.

It is proposed to study the impact of the COVID-19 pandemic on the example of such domestic enterprises of transport engineering and railway industry as JSC "Ukrzaliznytsia", PJSC "KVBZ", SE "UkrNDIV", LLC "LEMTRANS", LLC "KERNELPA-TRADE" car repair plant "(hereinafter - TDV" PVRZ"). The main activity of these enterprises is aimed at production, maintenance and repair, operation, as well as performing scientific and experimental research of railway equipment. Thus, JSC "Ukrzaliznytsia" is a national carrier of goods and passengers, which is the largest operator (owner) of rolling stock in the country. PJSC "KVBZ" is the only domestic machine-building enterprise with a full production cycle, which specializes in the manufacture of railway transport for social purposes and is the leader in the number of production of freight rolling stock in the country. SE "UkrNDIV" is a research institution that deals with the problems and development of the whole range of the rail rolling stock, and includes the Testing Center, Inspection and Certification Body for railcar-building products. LEMTRANS LLC and KERNEL-TRADE LLC are the leading private operators of railway rolling stock in Ukraine. LEMTRANS LLC is the largest private owner of the freight car fleet primarily consisting of open-top wagons. KERNEL-TRADE LLC is the largest domestic private owner (operator) of grain wagons. TDV "PVRZ" is an enterprise engaged in the production and repair of freight railway rolling stock, also involved in the manufacture of spare parts for the railway vehicles.

To analyze the activities of the above-mentioned domestic enterprises, the following main technical and economic indicators were selected: net income from sales of products (goods, works, services); cost of goods sold (goods, works, services); gross profit (loss); other operating income; other operating expenses, including administrative; pre-tax financial result; net financial result. The results of the analysis of technical and economic indicators of the above enterprises in 2019 and 2020 are given in Table 1.

The dynamics of growth (reduction) of technical and economic indicators of enterprises to the corresponding period last year are given in Table 2 .

Table 1. The results of the analysis of technical and economic indicators of JSC «Ukrzaliznytsia», PJSC «KVBZ», SE «UkrNDIV», LLC «LEMTRANS», LLC «KERNEL-TRADE», TDV «PVRZ» in 2019 and 2020 years [15-20]

\begin{tabular}{|l|c|c|c|c|c|c|}
\hline \multirow{2}{*}{ Name of indicators } & \multicolumn{6}{|c|}{2019} \\
\cline { 2 - 7 } & $\begin{array}{c}\text { JSC } \\
\text { "Ukrzaliznytsia }\end{array}$ & $\begin{array}{c}\text { PJSC } \\
\text { "KVBZ" }\end{array}$ & $\begin{array}{c}\text { SE } \\
\text { "UkrNDIV }\end{array}$ & $\begin{array}{c}\text { LLC } \\
\text { "LEMTRANS" }\end{array}$ & $\begin{array}{c}\text { LLC } \\
\text { "KERNEL- } \\
\text { TRADE" }\end{array}$ & $\begin{array}{c}\text { TDV } \\
\text { "PVRZ" }\end{array}$ \\
\hline $\begin{array}{c}\text { Net income from sales of } \\
\text { products (goods, works, } \\
\text { services) }\end{array}$ & 90352319 & 8310455 & 36058 & 14159825 & 51482928 & 2147380 \\
\hline $\begin{array}{c}\text { Cost of goods sold (goods, } \\
\text { works, services) * }\end{array}$ & 83568776 & $(6955615)$ & $(29680)$ & $(10895947)$ & $(45932765)$ & (2008020) \\
\hline
\end{tabular}


Continuation of the table 1

\begin{tabular}{|c|c|c|c|c|c|c|}
\hline Gross profit (loss) $*$ & 6783543 & 1354840 & 6378 & 3263878 & 5550163 & 139360 \\
\hline Other operating income* & 5888538 & 260401 & 6000 & 213171 & 777043 & 8997 \\
\hline \begin{tabular}{|c|}
$\begin{array}{c}\text { Other operating } \\
\text { expenses* }\end{array}$ \\
\end{tabular} & 7808734 & $(588981)$ & $(11811)$ & $(488296)$ & $(5956052)$ & $(51802)$ \\
\hline Pre-tax financial result $*$ & 4863347 & 1043757 & 567 & 183705 & 608977 & 97673 \\
\hline Net financial result $*$ & 2988247 & 828869 & 436 & 0 & 355787 & 78823 \\
\hline \multicolumn{7}{|c|}{2020} \\
\hline $\begin{array}{l}\text { Net income from sales of } \\
\text { products (goods, works, } \\
\text { services) * }\end{array}$ & 75291560 & 3337075 & 34269 & 14391017 & 67395769 & 750403 \\
\hline $\begin{array}{l}\text { Cost of goods sold } \\
\text { (goods, works, services) } \\
*\end{array}$ & 75930411 & $(3088254)$ & $(28561)$ & $(12375384)$ & $(58114495)$ & $(702954)$ \\
\hline Gross profit (loss) $*$ & $(638851)$ & 248821 & 5708 & 2015633 & 9281274 & 47449 \\
\hline Other operating income* & 1185203 & 306055 & 6860 & 201948 & 1666006 & 10035 \\
\hline $\begin{array}{ll}\text { Other } & \text { operating } \\
\text { expenses } * & \end{array}$ & (12480659) & $(459817)$ & (9647) & (434307) & $(5345080)$ & $(45398)$ \\
\hline Pre-tax financial result $*$ & $(11934307)$ & 87210 & 2931 & 492255 & 2022738 & 9641 \\
\hline Net financial result $*$ & $(11899687)$ & 71810 & 2335 & 440391 & 1648945 & 6227 \\
\hline
\end{tabular}

* Note: all technical and economic indicators in Table. 1. are given in thousands of hryvnias.

Table 2. Dynamics of growth (reduction) of technical and economic indicators of enterprises

\begin{tabular}{|c|c|c|c|c|c|c|}
\hline & $\begin{array}{c}\text { JSC } \\
\text { "Ukrzaliznytsia" }\end{array}$ & $\begin{array}{c}\text { PJSC } \\
\text { "KVBZ" }\end{array}$ & $\begin{array}{c}\text { SE } \\
\text { "UkrNDIV }\end{array}$ & $\begin{array}{c}\text { LLC } \\
\text { "LEMTRANS" }\end{array}$ & $\begin{array}{c}\text { LLC } \\
\text { "KERNEL- } \\
\text { TRADE" }\end{array}$ & $\begin{array}{c}\text { TDV } \\
\text { "PVRZ" }\end{array}$ \\
\hline $\begin{array}{c}\text { Net income from sales of } \\
\text { products (goods, works, } \\
\text { services) }\end{array}$ & $\downarrow 16,7 \%$ & $\downarrow 59,8 \%$ & $\downarrow 5,0 \%$ & $\uparrow 1,6 \%$ & $\uparrow 30,9 \%$ & $\downarrow 65,1 \%$ \\
\hline $\begin{array}{c}\text { Cost of goods sold } \\
\text { (goods, works, services) } \\
*\end{array}$ & $\downarrow 9,1 \%$ & $\downarrow 55,6 \%$ & $\downarrow 3,8 \%$ & $\uparrow 1,1 \%$ & $\uparrow 26,5 \%$ & $\downarrow 65,0 \%$ \\
\hline Gross profit (loss) $*$ & $\downarrow 7422394$ & $\begin{array}{c}\downarrow \\
1106019\end{array}$ & $\downarrow 670$ & $\downarrow 1248245$ & $\uparrow 3731111$ & $\downarrow 91911$ \\
\hline Other operating income* & $\downarrow 79,9 \%$ & $\uparrow 17,5 \%$ & $\uparrow 14,3 \%$ & $\downarrow 5,3 \%$ & $\uparrow 114 \%$ & $\uparrow 11,5 \%$ \\
\hline $\begin{array}{c}\text { Other operating } \\
\text { expenses* }\end{array}$ & $\uparrow 59,8 \%$ & $\downarrow 21,9 \%$ & $\downarrow 18,3 \%$ & $\downarrow 11,1 \%$ & $\downarrow 10,3 \%$ & $\downarrow 12,4 \%$ \\
\hline Pre-tax financial result $*$ & $\downarrow 16797654$ & $\downarrow 956547$ & $\uparrow 2364$ & $\uparrow 308550$ & $\uparrow 1413761$ & $\downarrow 88032$ \\
\hline Net financial result $*$ & $\downarrow 14887934$ & $\downarrow 757059$ & $\uparrow 1899$ & $\uparrow 440391$ & $\uparrow 1293158$ & $\downarrow 72596$ \\
\hline
\end{tabular}

According to the results of data analysis (Table 1-2) the following is established:

net income from sales of products (goods, works, services) in 2020 compared to 2019 in JSC "Ukrzaliznytsia", PJSC "KVBZ", SE "UkrNDIV", TDV "PVRZ" decreased by 5.0-65.1\%, while for LLC "LEMTRANS" and LLC "KERNEL-TRADE" this figure increased by $1.6 \%$ and $30.9 \%$ respectively;

the cost of goods sold (goods, works, services) in 2020 compared to 2019 had a dynamic reduction in JSC "Ukrzaliznytsia", PJSC "KVBZ", SE "UkrNDIV", TDV "PVRZ" at the level of 3.8-65.0\% and the dynamics of increase in LLC "LEMTRANS" and LLC "KERNEL-TRADE" by $1.1 \%$ and $65.0 \%$ respectively;

almost proportional increase or decrease in net income from sales of products (goods, works, services) and cost of goods sold (goods, works, services) at domestic enterprises indicates that the unit 
cost of production has not changed significantly (the spread of values is recorded at $0.1-7.6 \%$ ). The maximum scatter of values, comparing these indicators, is observed in JSC "Ukrzaliznytsia";

gross profit following the results of work in 2019 was observed in all the above-mentioned domestic enterprises, while in 2020 JSC "Ukrzaliznytsia" received gross loss, all other enterprises received gross profit;

other operating income in 2020 had the dynamics of increase in PJSC "KVBZ", SE "UkrNDIV", LLC "KERNEL-TRADE", TDV "PVRZ" at 11.5-114\%, while JSC "Ukrzaliznytsia" and LEMTRANS LLC showed the dynamics of decrease by $79.9 \%$ and $5.3 \%$, respectively;

other operating expenses in 2020 had an increase in dynamics only for JSC "Ukrzaliznytsia" and amounted to $59.8 \%$, in other enterprises a dynamics of decrease at $10.3-21.9 \%$ is observed;

financial result before tax and the net financial result in 2020 had a positive dynamics in SE "UkrNDIV", LLC "LEMTRANS", LLC "KERNEL-TRADE" and, accordingly, negative dynamics in JSC "Ukrzaliznytsia", PJSC "KVBZ", TDV "PVRZ". Moreover, following the results of work in 2020 JSC "Ukrzaliznytsia" showed a loss of 11899687 thousand UAH.

Thus, it was established that the national railway operator, railcar-building and car-repair enterprises were mostly affected financially in 2020 following the introduction of quarantine measures. The research institution should be categorized as less affected enterprises. In the conditions of the COVID-19 pandemic, private operators of railway rolling stock of Ukraine were even able to increase sales volumes and increase the net financial result compared to last year.

From the analysis of the given data it is noticeable that there was a significant reduction in the performance of domestic enterprises of transport engineering and the railway industry, with the exception of private operators of railway rolling stock. However, it is difficult to unambiguously define the root causes of such decrease, despite the coincidence in time with the introduction of quarantine measures in the country. Therefore, in the future it is proposed to conduct a detailed analysis of possible causes of reduction in technical and economic indicators of domestic railway enterprises, primarily the national railway operator, car-building and car-repair enterprises.

To find out the most important reasons for the reduction in technical and economic indicators at the relocated enterprises of the transport engineering and railway industries, as well as to study the impact of the COVID-19 pandemic on these indicators, an expert evaluation study was performed. The method of expert evaluation involves the definition of the object of study, proposed to experts for the evaluation of objects (criteria), the selection of experts and their rank of competence.

The object of the study is domestic enterprises of transport engineering and railway industry, which have degraded technical and economic performance of their activities in 2020. To assess the experts proposed ten criteria (factors), which characterize the main reasons for the significant reduction in technical and economic performance of enterprises. It is proposed to determine the most important reasons for degradation of indicators and the impact of the consequences of the COVID-19 pandemic on these indicators by setting expert weighting factors for each proposed criterion (factor). The following main reasons were accepted as criteria (factors):

1) the impact of quarantine measures to prevent the spread of the COVID-19 pandemic (IM1);

2) the lack of a state program to support and promote the development of transport engineering and the railway industry in the country (IM2); competition from other modes of transport (road, water, air) due to rising costs, deteriorating quality and service of railway products (goods, works, services) (IM3);

4) stronger competition from foreign enterprises (IM4);

5) reduction of production in related sectors of the economy (IM5);

6) aging and physical wear and tear of property complexes, lack of implementation of efficient equipment and resource-saving technologies in transport engineering and railway industry resulting in deteriorating quality of goods and services (IM6);

7) decrease in the purchasing power of consumers in transport machine-building and the railway industry (IM7);

8) lack of protection of the interests of domestic enterprises during the tender procedure at the level of legislation (IM8); 
9) closure of markets for railway products abroad due to the introduction of restrictions at the legislative level and increasing the tax burden (IM9);

10) increasing the cost of energy, fuel and lubricants, heat, etc. (IM10).

The group of experts includes specialists from domestic enterprises and research institutions whose activities are related to the railway industry. During the research it was accepted that the competence level of experts is constant.

Each of the experts determines the weight of a particular criterion so that the total sum of the weights is equal to one hundred points. According to each of the $j$ experts, a certain factor $i$ has an impact of varying degrees on the object of study. According to the degree of influence determined by the expert, the criteria (factors) are ranked, the results of which are presented in the form of a matrix.

The consistency of experts' opinions is determined by the concordance correlation coefficient, which is determined by the expression [21, 22]:

$$
K_{\text {кон }}=\frac{\sum_{j=1}^{n} d_{j}^{2}}{\frac{1}{12} \cdot\left[m^{2}\left(n^{3}-n\right)-m \sum_{i=1}^{m} T_{i}\right]},
$$

$L$ is a number of groups of related (identical) ranks; $t_{e}$ is the number of related ranks in each group;

$n$ is the number of options offered to experts; $m$ is the number of experts participating in the survey;

$S_{j}$ is the sum of ranks; $d_{j}$ is the deviation of the rank sum from the average rank sum.

After making sure that the opinions of experts are consistent, a chart of ranks is built. The degree of influence of criteria (factors) on the object of study is assessed by the rank sum: the greater the rank sum of a factor, the greater the impact of this factor on the object of study.

Next, the values of such important indicators as weight of the criterion (factor), variation scale, standard deviation, coefficient of variation are calculated. These indicators are calculated in order to analyze the variance and consistency of expert assessments.

The weight of the criterion (factor), calculated according to all experts $\left(w_{i}\right)$, is equal to [21, 22]:

$$
w_{i}=\frac{\sum_{i=1}^{m} w_{i j}}{m}, i=\overline{1, n}
$$

Where $w_{i j}$ is the weight of the $i$ - th object, determined by the estimates of the $j$ - th expert, is equal to:

$$
w_{i j}=\frac{x_{i j}}{\sum_{i=1}^{n} x_{i j}}, i=\overline{1, n}, j=\overline{1, m}
$$

Where $x_{i j}$ is the estimate of the $i$-th criterion (factor) given by the expert.

The variation range is calculated by the well-known expression [21]:

$$
R=x_{\text {max }}-x_{\text {min }}
$$


Where,

$x_{\max }$ is the maximum score of the criterion (factor); $x_{\min }$ is the minimum score of the criterion (factor).

The standard deviation is calculated by the known formula [22]:

$$
\sigma=\sqrt{\frac{\sum_{j=1}^{m}\left(x_{j}-\bar{x}_{\ni}\right)^{2}}{m-1}},
$$

Where, $\bar{x}_{\ni}$ is the average value of the evaluation of the criterion (factor) based on the results of the survey of all experts. The coefficient of variation is calculated by the expression [21]:

$$
V=\frac{\sigma}{x_{\ni}} \cdot 100
$$

In our case, when determining the weighting factors $n=10, m=10$.

The results of expert evaluation of the weights of the criteria (factors) in the form of a matrix are given in Table. 3. The results of the analysis of the determination of weighting factors by experts are given in Table. 4.

Table 3. The results of expert evaluation of weighting factors

\begin{tabular}{|c|c|c|c|c|c|c|c|c|c|c|}
\hline \multirow{2}{*}{ No. of the expert } & \multicolumn{10}{|c|}{ Expert criterion (factor) of influence } \\
\cline { 2 - 12 } & IM1 & IM2 & IM3 & IM4 & IM5 & IM6 & IM7 & IM8 & IM9 & IM10 \\
\hline 1 & 3 & 10 & 10 & 5 & 7 & 7 & 3 & 20 & 20 & 15 \\
\hline 2 & 5 & 25 & 5 & 10 & 10 & 15 & 5 & 5 & 10 & 10 \\
\hline 3 & 0 & 15 & 15 & 5 & 10 & 5 & 10 & 10 & 25 & 5 \\
\hline 4 & 5 & 30 & 5 & 5 & 5 & 10 & 20 & 5 & 5 & 10 \\
\hline 5 & 15 & 15 & 10 & 5 & 10 & 15 & 10 & 10 & 5 & 5 \\
\hline 6 & 15 & 20 & 10 & 5 & 10 & 10 & 10 & 10 & 5 & 5 \\
\hline 7 & 10 & 30 & 5 & 0 & 5 & 5 & 10 & 5 & 20 & 10 \\
\hline 8 & 5 & 20 & 10 & 20 & 5 & 10 & 10 & 10 & 5 & 5 \\
\hline 9 & 15 & 15 & 20 & 2 & 5 & 10 & 13 & 10 & 5 & 5 \\
\hline 10 & 8 & 16 & 6 & 7 & 8 & 15 & 7 & 14 & 5 & 14 \\
\hline
\end{tabular}

Table 4. Results of statistical analysis of expert evaluation of weights coefficients

\begin{tabular}{|c|c|c|c|c|c|c|c|c|c|c|}
\hline $\begin{array}{c}\text { Name of the } \\
\text { indicator }\end{array}$ & \multicolumn{10}{|c|}{ Criterion (factor) of influence } \\
\cline { 2 - 14 } & IM1 & IM2 & IM3 & IM4 & IM5 & IM6 & IM7 & IM8 & IM9 & IM10 \\
\hline Average value & 8,1 & 19,6 & 9,6 & 6,4 & 7,5 & 10,2 & 9,8 & 9,9 & 10,5 & 8,4 \\
\hline Weighting factor & 0,081 & 0,196 & 0,096 & 0,064 & 0,075 & 0,102 & 0,098 & 0,099 & 0,105 & 0,084 \\
\hline Variation scope & 15 & 20 & 15 & 20 & 5 & 10 & 17 & 15 & 20 & 10 \\
\hline RMSD & 16,3 & 20,1 & 14,2 & 16,4 & 7,1 & 10,6 & 13,6 & 13,3 & 23,4 & 10,6 \\
\hline $\begin{array}{c}\text { Coefficient of } \\
\text { variation }\end{array}$ & 202 & 102 & 148 & 256 & 95 & 104 & 139 & 134 & 222 & 126 \\
\hline $\begin{array}{c}\text { Concordance } \\
\text { coefficient }\end{array}$ & \multicolumn{10}{|c|}{0,54} \\
\hline
\end{tabular}

The obtained values (Table 4) demonstrate the satisfactory consistency of the expert evaluation. The analysis of the received data showed that the absence of the state program of support and development promotion of the railway industry in the country (the rank of this factor makes 0,196 ) has the greatest weight. Also important reasons, according to experts, are the closure of markets for railway products abroad due to other legislative restrictions and increased tax burden (rank 0.105) and aging and physical wear and tear of property complexes, lack of effective equipment and resource-

Збірник наукових праць ДУІТ. Серія «Транспортні системи і технологї̈, 2021. Вип. 38 
saving technologies in transport engineering and railway industry (rank 0.102). The rank of the impact of the consequences of the introduction of quarantine measures to counter the pandemic COVID-19 experts estimate at 0.081 .

The data results given in Table 1-4 indicate the need and relevance of identifying possible ways to overcome the effects of the COVID-19 pandemic in domestic transport engineering and railway enterprises. Among the possible ways or measures that would allow in the near future to improve the technical and economic performance of the most affected domestic enterprises of transport engineering and the railway industry, the following should be noted:

introduction of gradual decommissioning of worn-out rolling stock with expired service life and simultaneous renewal of the rolling stock;

development and approval of a comprehensive rolling stock renewal program in Ukraine with effective mechanisms for monitoring its implementation;

development and approval of the State target program of support and development of the railway engineering industry with effective mechanisms for monitoring its implementation;

improvement of the legal field in the field of instruments of trade protection of railway products (goods, works, services) of domestic enterprises, including protection against increased protectionism of other states;

the need to introduce a mechanism for lending for the purchase of modern efficient equipment and energy-saving technologies under state guarantees;

increasing the availability of credit resources for the introduction of modern efficient equipment and resource-saving technologies;

stimulating the attraction of investments in the development of transport engineering and railway industry at the state level;

reduction in tax burden on the import of innovative equipment for the needs of transport engineering enterprises and the railway industry, which is not manufactured in Ukraine; acceleration of the adoption of a new version of the Law of Ukraine "On Railway Transport"; implementation of effective measures to prevent the loss of qualified personnel;

development of necessary conditions for support and encouragement of acquisition of modern innovative rolling stock of domestic production;

development of a fundamentally new credit and leasing policy for domestic buyers of railway rolling stock of Ukrainian producers;

creation of conditions for a full cycle of service by domestic enterprises on the territory of Ukraine of previously purchased high-tech railway products of foreign production;

import substitution of high-tech railway equipment and its components;

establishment of the minimum level of localization of production of complex high-tech railway products in the country during the implementation of tender procurement at the legislative level; approval of the branch methodology for determining the degree of localization of production of high-tech products (railway equipment) and the methodology for determining the life cycle costs; introduction of new approaches in the implementation of freight and passenger transportation, which would meet modern world trends in railway development and improve the quality and service of services;

making changes to technical documents and instructions for the repair of rolling stock, aimed at improving the quality and frequency of scheduled work for cars with extended service life;

introduction of a recycling fee when importing into the customs territory of Ukraine rolling stock that was in use depending on the terms of its operation and type.

Comprehensive implementation of the above measures will not only improve the financial and economic performance of domestic enterprises, but also solve a range of strategic objectives that will contribute to the development of Ukraine's economy. Among which are the following:

filling the budgets of all levels with taxes;

creation of additional jobs, removal of social tensions related to unemployment; 
increase in the financing of the budget sphere due to additional tax revenues and prevention of additional unemployment expenses;

increasing the safety of transportation and defense capabilities of the state;

meeting the needs of railways and industrial enterprises of Ukraine with rolling stock used for passenger and freight transportation, as well as for the maintenance and development of railway infrastructure;

assistance in scientific and technical development of the domestic railway industry and raising the professional training of specialized specialists of Ukraine to a higher level;

reduction in immigration of highly qualified personnel abroad;

increase in economic and social indicators of development of related sectors of the economy;

improvement of the quality of transport services provided by rail;

reduction in import dependence of the state, reduction of trade balance and strengthening of export opportunities;

introduction of advanced design, technological and scientific and technical solutions;

increasing the level of energy saving and indicators of use of other available resources;

reduction of negative impact on the environment (increasing the level of environmental

friendliness);

attraction of additional investments in the domestic railway industry;

creation of competitive innovative rolling stock with improved technical and economic indicators;

reduction of operating costs for maintenance and repair of rolling stock, as well as reduction of unit costs for the provision of transport services;

reduction of depreciation of fixed assets of domestic enterprises of the railway industry.

\section{Conclusions}

1. The results of the analysis of these technical and economic indicators of domestic enterprises of transport machine-building and railway industry allowed establishing that the conditions of quarantine measures mostly affected the national railway operator, railcar-building and car-repair enterprises. Net income from sales of products (goods, works, services) at these enterprises decreased by 16.7-65.1\%. At the same time, the net financial result had a negative dynamics (in JSC "Ukrzaliznytsia" following the results of 2020 there was a loss of almost 12 billion UAH). In the conditions of the COVID-19 pandemic, private operators of freight rolling stock in Ukraine LLC "LEMTRANS" and LLC "KERNEL-TRADE" were able to increase sales of products (goods, works, services) by $1.6 \%$ and $30.9 \%$ respectively, and also to improve the net financial result by over UAH 440 million and UAH 1293 million, respectively, compared to the previous year.

2 . The results of the analysis of expert evaluation data allowed determining that the most important reason for the reduction in technical and economic indicators at domestic enterprises is the lack of a state program to support and stimulate the development of transport engineering and railway industry in the country). Also important reasons for the impact of experts are the closure of markets for railway products abroad due to the introduction of restrictions by other countries at the legislative level and increase the tax burden (10.5\%) and aging and physical wear and tear of property complexes, lack of efficient equipment and energy-saving technologies (10,2\%). Experts estimate the impact of the consequences of the introduction of quarantine measures to counter the COVID-19 pandemic at 8.1\%.

3. Measures have been proposed that would allow in the near future to improve the technical and economic performance of the most affected domestic enterprises of transport machine-building and the railway industries and to promote the development of Ukraine's economy as a whole.

\section{REFERENCES}

1. Dolbnieva D.V., (2020). Vliianiie COVID-19 na ekonomiku stran mira. [The impact of COVID-19 on the world economy]. Probliemy ekonomiki - Problems of the economy, p. 20-26. https://doi.org/10.32983/2222-0712-2020-1-20-26 [in Russian] 
2. Pandemiia COVID-19. Biolohiia i ekonomika [The COVID-19 pandemic. Biology and economics]. (2020). Spetsialnyi vypusk: informatsionno-analytycheskii sbornyk - Special issue: information-analytical collection. M.F. Mizintseva (Ed.). VINITI RAN. Moscow: Izdatelstvo Pero [Text] [in Russian]

3. Flahault A. Lancet. (2020). COVID - 19 cacophony: is there any orchestra conductor?, 395, No. 10229, p. 1037-1038. Eng. DOI: 10.1016 / S0140-6736 (20) 30675-9

4. Legido-Quigley H., Mateos-Garcia J.T., Campos V.R., Gea-Sanchez M., Muntaner C. \& McKee M. (2020, March 18). The resilience of the Spanish health system against the COVID-19 pandemic. Lancet Pub. Health. Published online., p. 1-2. Eng. DOI: 10.1016 / S2468-2667 (20) 30060-8

5. Kannan S., Shaik Syed Ali P., Sheeza A. \& Hemalatha K. (2020). Novel Coronavirus 2019 - recent trends / Eur. Rev. Med. and Pharmacol.SCi.. 24, No. 4, p. 2006-2011.Eng. DOI: 10.26355 / eurrev_202002_20378.

6. Dolhov S. Y., Savinov Yu. A., \& Taranovskaia E. V., (2020). Vliianiie vspyshki novoho koronavirusa na mezhdunarodnuiu torhovliu [The impact of a new coronavirus outbreak on international trade]. Rosiiskii vnieshnieekonomicheskii vestnik - Russian Foreign Economic Journal, 2, p. 7-18 [in Russian]

7. Taylor L.H., Latham S.M., Woolhouse M.E. (2001). Risk factors for human disease emergence. Philos. Trans. R. Soc. London. Ser. B Biol. Sci., №. 356, pp. 983-989.

8. Puriwat, W., Tripopsakul, S. (2021). Customer Engagement with Digital Social Responsibility in Social Media: A Case Study of COVID-19 Situation in Thailand. Journal of Asian Finance, Economics and Business, 8 (2), 475-483. doi: http://doi.org/10.13106/ jafeb.2021.vol8.no2.0475

9.Giones, F., Brem, A., Pollack, J. M., Michaelis, T. L., Klyver, K., Brinckmann, J. (2020). Revising entrepreneurial action in response to exogenous shocks: Considering the COVID-19 pandemic. Journal of Business Venturing Insights, 14, e00186. doi: https:// doi.org/10.1016/j.jbvi.2020.e00186

10. Zhan, J. (2020). Covid-19 and investment - an UNCTAD research round-up of the international pandemic's effect on FDI flows and policy. Transnational Corporations, 27 (1), 1-2. doi: https://doi.org/10.18356/42625ea1-en

11. Kruhlyi D.H., (2020). Doslidzhennia stanu morskykh perevezen pid chas pandemii. Transportni systemy i tekhnolohii [Study of the state of maritime transport during a pandemic. Transportni systemy i technolohii Zbirnyk naukovykh prats Derzhavnoho universytetu infrastruktury ta tekhnolohii - Transport systems and technologies. Collection of scientific works of the State University of Infrastructure and Technologies, 36. pp. 143-149. doi: https: //doi.org/10.32703/2617-9040-202036-15 [in Ukrainian]

12. Vodovozov Ye. N., Rudachenko O. O., (2021). Rozrobka metodyky zabezpechennia protektsionizmu pidpryiemnytstva $\mathrm{v}$ konteksti finansovykh kapitalovkladen $\mathrm{z}$ metoiu reabilitatsii transportnoho sektoru [Development of methods for ensuring the protectionism of entrepreneurship in the context of financial investments to rehabilitate the transport sector]. Eastern-European Journal of Enterprise Technologies, Volume 4, 13 (112), pp. 34-41. doi: https://doi.org/10.15587/1729-4061.2021.238414 [in Ukrainian]

13. Dvulit Z. P., Danyliuk I. A. Vplyv COVID-19 na rynok vantazhnykh zaliznychnykh perevezen [Influence of COVID19 on the market of freight railway transportation]. URL: http: //science.lpnu.ua/uk/smeu/vsi-vypusky/vypusk-2-nomer- 22020 / vplyv-sovid-19- na-rynok-vantazhnyh-zaliznychnyh-perevezen (Accessed: October 28, 2021).

14. Hladkykh I.V., Lupitko N.V. (2021). Doslidzhennia naslidkiv vplyvu pandemii COVID-19 na diialnist pidpryiemstv zaliznychnoho transport [Study of the consequences of the COVID-19 pandemic on the activities of railway transport enterprises]. Reikovyi rukhomyi sklad. Zbirnyk naukovykh prats Derzhavnoho pidpryiemstva «Ukrainskyi NaukovoDoslidnyi Instytut Vahonobuduvannia» - "Railbound rolling stock". Collection of scientific works of the State Enterprise "Ukrainian Scientific Railway Car Building Research Institute", 22. pp. 18-31. doi: https://doi.org/10.47675/2304-63092021-22-18-31 [in Ukrainian]

15.DERZHAVNE PIDPRYIEMSTVO "UKRAINSKYI NAUKOVODOSLIDNYI INSTYTUT VAHONOBUDUVANNIA". Zvit pro finansovi rezultaty (Zvit pro sukupnyi dokhid) za rik 2020 - STATE ENTERPRISE "UKRAINIAN RESEARCH INSTITUTE". Report on financial results (Statement of comprehensive income) for the year 2020. URL: https://ukrndiv.com.ua/wp-content/uploads/2021/05/F2.-Zvit-pro-finansovi-rezultaty-v-tysyachah -.pdf (Accesses October 28, 2021) [in Ukrainian]

16. Publichne aktsionerne tovarystvo «Kriukivskyi vahonobudivnyi zavod». Okrema finansova zvitnist u vidpovidnosti do MSFZ za rik, shcho zakinchyvsia 31 hrudnia 2020 roku - Public Joint Stock Company "Kryukiv Railway Car Building Plant". Separate financial statements in accordance with IFRS for the year ended 31 December 2020. URL: https: //www.kvsz.com/images/stories/doc/FIN_ZVIT_2020.pdf (Accessed 28.10.2021) [in Ukrainian]

17. RAKhUNKOVA PALATA. ZVIT pro rezultaty audytu efektyvnosti aktsionernoho tovarystva "Ukrainska zaliznytsia" z pytan vykorystannia i rozporiadzhennia derzhavnym mainom rehionalnoiu filiieiu "Pivdenno-Zakhidna zaliznytsia", shcho maiut finansovi naslidky dlia derzhavnoho biudzhetu. Zatverdzheno rishennia Rakhunkovoi palaty vid 13.10.2020 № 27-3 - ACCOUNTING CHAMBER. REPORT on the results of the audit of the effectiveness of the joint-stock company "Ukrainian Railways" on the use and disposal of state property by the regional branch of the "South-Western Railway", which have financial implications for the state budget. Approved decision of the Accounting Chamber dated 13.10.2020 No. 27-3. URL: https: //rp.gov.ua/upload-files/Activity/Collegium/2020/27-3_2020/Zvit_27-3_2020.pdf (Application date 28.10.2021) [in Ukrainian]

18. Tovarystvo $\mathrm{z}$ obmezhenoiu vidpovidalnistiu «LEMTRANS» Okrema finansova zvitnist za MSFZ ta zvit nezalezhnoho audytora 31 hrudnia 2020 r.LEMTRANS - Limited Liability Company. Separate financial statements in accordance with IFRS and the report of the independent auditor on December 31, 2020. URL: https://www.lemtrans.com.ua/uploads/files/60b484c4970d0492340670.pdf (Date of application 28.10.2021) [in Ukrainian]

Збірник наукових праць ДУІТ. Серія «Транспортні системи і технологї̈», 2021. Вип. 38 
19. Tovarystvo $\mathrm{z}$ obmezhenoiu vidpovidalnistiu "KERNEL-TREID". Zvit pro finansovi rezultaty (Zvit pro sukupnyi dokhid) za 2020 rik KERNEL-TRADE Limited Liability Company. Report on financial results (Report on total income) for 2020. URL: http: //kerneltrade.prat.in.ua/files/builders/81958/documents/461282/doc_84363.pdf (Accessed: October 28, 2021) [in Ukrainian]

20. Tovarystvo z dodatkovoiu vidpovidalnistiu "Popasnianskyi vahonoremontnyi zavod". Zvit pro finansovi rezultaty (Zvit pro sukupnyi dokhid) za 2020 rik -Popasnyansky Car Repair Plant Additional Liability Company. Report on financial results (Statement of comprehensive income) for 2020. URL: http: //www.pvrz.org.ua/company/public-information/financialreport-2020.pdf (Accessed: October 28, 2021) [in Ukrainian]

21. Horbunov M.I. (2018). Vyznachennia perspektyvnykh metodiv pidvyshchennia efektyvnosti halmuvannia $\mathrm{Z}$ vykorystanniam ekspertnoho otsiniuvannia [Identification of promising methods to increase the efficiency of braking using expert evaluation]. Zbirnyk naukovykh prats DUIT. Seriia «Transportni systemy i tekhnolohii» - Collection of scientific works of DUIT. Transport Systems and Technologies series, 31, (p. 93-101). Kyiv: DUIT [in Ukrainian]

22. Hrabovetskyi, B.Ie. (2010). Metody ekspertnykh otsinok: teoriia, metodolohiia, napriamky vykorystannia [Methods of expert evaluations: theory, methodology, directions of use]. Monograph. Vinnytsia: VNTU [in Ukrainian].

\section{Андрій Сулим ${ }^{1 *}$, Олександр Сафронов ${ }^{1}$,нна Гладких ${ }^{1}$, Надія Лупітько ${ }^{I}$}

1 Державне підприємство «Український науково-дослідний інститут вагонобудування», вул. I. Приходька, 33, м. Кременчук, 39621, Україна

\section{ДОСЛІДЖЕННЯ ПОКАЗНИКІВ РОБОТИ ПІДПРИСМСТВ ТРАНСПОРТНОГО МАШИНОБУДУВАННЯ ТА ЗАЛІЗНИЧНОЇ ГАЛУЗІ В УМОВАХ ПАНДЕМІЇ COVID-19}

В статті проаналізовано питання впливу наслідків від запровадження карантинних заходів протидї пандемії COVID-19 на діяльність економіки України в цілому та вітчизняного транспортного машинобудівного сектора зокрема. Встановлено, щьо одними з найбільш постраждалих секторів економіки є транспорт та машинобудування, зокрема галузь залізничного транспорту. Визначено, щео на даний час досить актуальним питанням для подальшого розвитку вітчизняних підприємств транспортного машинобудування та залізничної галузі, є оиінка впливу пандемії COVID-19 на діяльність та фінансово-господарські показники ичих підприємств. Проаналізовано та досліджено фінансово-господарські показники таких вітчизняних підприємств транспортного машинобудування та залізничної галузі як АТ «Укрзалізниия», ПАТ «КВБЗ», ДП «УкрНДІВ», ТОВ «ЛЕМТРАНС» та ТОВ «КЕРНЕЛ-ТРЕЙД», ТДВ «Попаснянський вагоноремонтний завод». Визначено, щз з досліджуваних вітчизняних підприємств за умов введення карантинних заходів найбільш постраждалими виявились $A T$ «Укрзалізничя», ПАТ «КВБЗ», ТДВ «Попаснянський вагоноремонтний завод». Досліджено основні причини погіршення техніко-економічних показників на вітчизняних підприємствах транспортного машинобудування та залізничної галузі методом експертного оиінювання. За результатами аналізу даних експертного оиінювання встановлено, що найвагомішою причиною погіршення технікоекономічних показників підприємств є відсутність державної підтримки та стимулювання розвитку транспортного машинобудування $i$ залізничної галузі в країні $(19,6$ \%). Вплив наслідків введення карантинних заходів протидії пандемії COVID-19 експерти оцінюють на рівні 8,1\%. Запропоновано заходи для покращення техніко-економічних показників найбільш постраждалих вітчизняних підприємств транспортного машинобудування та залізничної галузі в умовах пандемії COVID-19.

Ключові слова: вітчизняне підприємство, залізнична галузь, пандемія COVID-19, ресурсоенергозберіючі технології, техніко-економічні показники, транспортне машинобудування. 